\title{
Research on Composite Bolt Foundation Design for Transmission Lines
}

\author{
Xinmin Yu ${ }^{1}$, Xianri Wang ${ }^{2}$ \\ ${ }^{1}$ Structural engineering, State GRID Fujian Economic Research Institute, FuZhou, FuJian, 350000, China \\ ${ }^{2}$ Power System and Automation, State GRID Fujian Economic Research Institute, FuZhou, FuJian, 350000, China
}

\begin{abstract}
There are various forms of foundation used in transmission line engineering, which can be divided into undisturbed soil foundation and non-undisturbed soil foundation according to the form of stress. In view of the geological condition that the upper layer has a thick overburden and the lower layer is rock, the composite bolt foundation is recommended to make full use of its upper undisturbed soil.
\end{abstract}

\section{Introduction of composite bolt foundation}

(1) Composite bolt foundation based on pile

Composite bolt foundation based on pile is a composite foundation composed of hole digging foundation and rock bolt, which is suitable for the geological conditions of thick upper overburden and easy to cut and dig, and the lower part is strong - medium weathering bedrock. The upper undisturbed soil excavation foundation adopts straight column type, which is formed by cutting and digging, and the bottom is not enlarged. Its bearing capacity is similar to the pile foundation model, and the upper pull or lower pressure bearing capacity is mainly provided by the lateral friction resistance of the foundation. The bottom of the upper excavation foundation shall enter the lower strongly weathered bedrock at least $0.5 \mathrm{~m}$ above to ensure the working behavior of the rock bolt at the bottom. The length of the rock bolt top anchored into the upper hole excavation pile foundation should meet the minimum anchorage length of reinforcement. ${ }^{[1]}$

(2) Embed composite bolt foundation

Embedded composite anchor foundation is a composite foundation composed of rock embedded foundation and rock anchor. It is suitable for rock foundation with slope of $£ 30^{\circ}$ and overburden thickness of more than $2 \mathrm{~m}$. The upper rock fixed foundation is the same as the conventional type. ${ }^{[2]}$ The hole is cut and dug, and the enlarged head is at the bottom and at least ensures that the enlarged head completely enters the lower strongly weathered bedrock, so as to ensure that the shear capacity of the surrounding rock can be fully utilized and the anti-pulling and anti-overturning capacity of the foundation can be improved. The length of bottom rock anchor into upper rock embedded foundation should meet the minimum anchorage length of reinforcement. ${ }^{[3]}$

The structural schematic diagrams of the two types of composite bolt foundation are shown in Figure $\mathbf{1}$ and Figure 2.

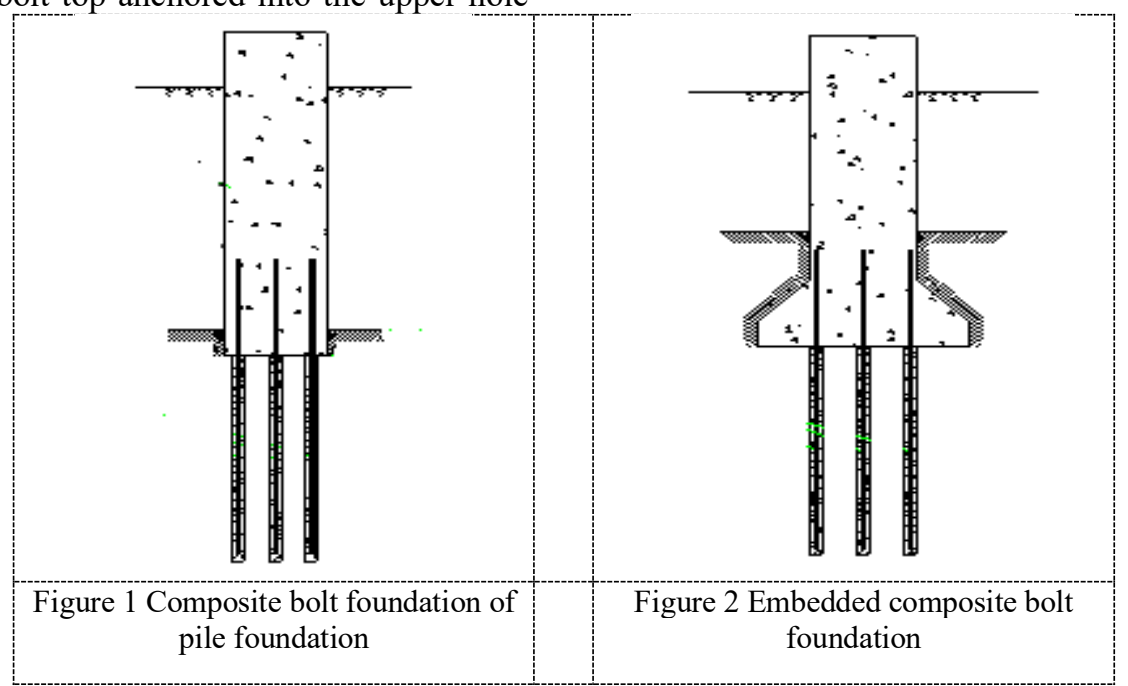

"E-mail: 110903205@qq.com 
Table 1 List of composite bolt foundation

\begin{tabular}{|c|c|c|c|c|}
\hline \multirow[b]{2}{*}{$\begin{array}{l}\text { Basis } \\
\text { type }\end{array}$} & \multicolumn{3}{|c|}{ Suitable conditions } & \multirow[b]{2}{*}{ Basic features and requirements } \\
\hline & $\begin{array}{l}\text { Mounta } \\
\text { in slope }\end{array}$ & $\begin{array}{c}\text { Cover } \\
\text { thicknes } \\
\mathrm{s}\end{array}$ & $\begin{array}{c}\text { Geotechnical } \\
\text { category }\end{array}$ & \\
\hline $\begin{array}{l}\text { Composi } \\
\text { te bolt } \\
\text { foundati } \\
\text { on with } \\
\text { pile } \\
\text { foundati } \\
\text { on }\end{array}$ & $\begin{array}{l}\text { There } \\
\text { is no } \\
\text { limit }\end{array}$ & $\begin{array}{l}\text { There is } \\
\text { no limit }\end{array}$ & $\begin{array}{l}\text { Upper overlying } \\
\text { soil can be cut } \\
\text { shape, not easy } \\
\text { to collapse, the } \\
\text { lower part of the } \\
\text { strong - } \\
\text { weathering rock } \\
\text { foundation }\end{array}$ & $\begin{array}{l}\text { 1. Cut and dig the upper part into a straight column } \\
\text { without expanding the bottom; } \\
2 \text {. The full depth of the excavation foundation end into the } \\
\text { bedrock is no less than } 0.5 \mathrm{~m} \text {; } \\
3 \text {. Rock bolt shall be set in the bedrock, and the top of the } \\
\text { bolt shall be anchored into the upper hole digging } \\
\text { foundation and meet the minimum anchorage length } \\
\text { requirements; } \\
\text { 4. The bottom anchor bar can be replaced by the main bar } \\
\text { of the upper foundation column }\end{array}$ \\
\hline $\begin{array}{c}\text { Fixed } \\
\text { composit } \\
\text { e bolt } \\
\text { foundati } \\
\text { on }\end{array}$ & $\begin{array}{c}30^{\circ} \text { or } \\
\text { less }\end{array}$ & $\begin{array}{l}\text { The } \\
\text { thicknes } \\
\text { s of } \\
\text { overbur } \\
\text { den } \\
\text { is }>2 \mathrm{~m}\end{array}$ & $\begin{array}{l}\text { The upper part } \\
\text { is overlaid with } \\
\text { soil, and the } \\
\text { lower part is } \\
\text { strongly } \\
\text { weathered rock } \\
\text { foundation }\end{array}$ & $\begin{array}{l}\text { 1. The upper rock is embedded with a foundation, and the } \\
\text { bottom is provided with an enlarged head; } \\
\text { 2. At least ensure that the enlarged head of the embedded } \\
\text { foundation fully enters the bedrock; } \\
\text { 3. Rock bolt is set in the bedrock, and the top of the bolt is } \\
\text { anchored into the upper foundation to meet the minimum } \\
\text { anchorage length requirement; } \\
\text { 4. The bottom anchor bar can be replaced by the main bar } \\
\text { of the upper foundation column }{ }^{[5]}\end{array}$ \\
\hline
\end{tabular}

According to the test results of composite bolt foundation, the total pulling capacity of composite bolt foundation is much higher than that of excavated pile or embedded foundation and rock bolt foundation of the same size. However, due to the displacements of the upper undisturbed foundation and the rock bolt at the bottom when they reach the ultimate bearing capacity respectively under the action of anti-pulling load ${ }^{[6]}$, the ultimate carrying capacity of the composite bolt foundation is not a simple superposition of the upper undisturbed foundation and the rock bolt foundation, but has a certain play proportion.

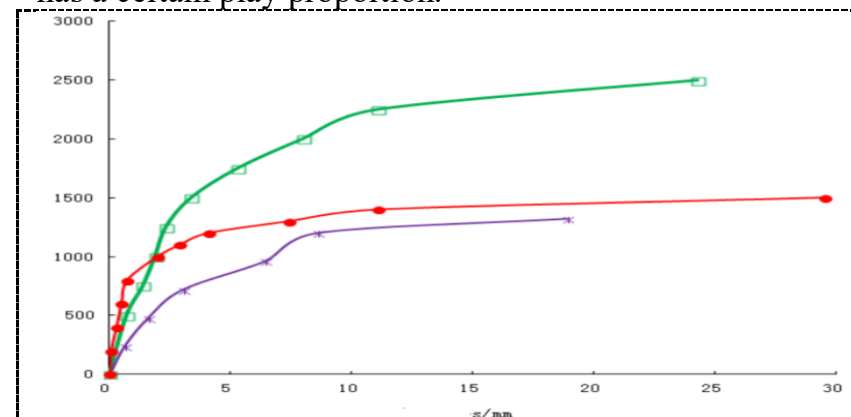

Figure 3 Results of drawing test of composite bolt foundation based on representative pile foundation in the past

The proportional coefficient of bearing capacity is related to the type of undisturbed soil foundation and the properties of subgrade soil and rock. Therefore, it is suggested that when composite bolt foundation is applied in combination with geological conditions on a pilot basis, corresponding in-situ true type tests should be carried out synchronously to determine the proportion coefficient of anti-pull limit development of the upper unchanging foundation and the bottom bolt foundation. ${ }^{[7]}$

In addition, for composite bolt foundation based on pile foundation, selecting appropriate rock-socketed depth can reduce or completely eliminate the bending moment at the bottom of the foundation, so that the bolt at the bottom is in a uniform axial tension state, which can further reduce the amount of foundation engineering. It is suggested that the value of rock-socketed depth of composite bolt foundation based on pile foundation should be reasonably determined through true type test results.

\section{Technical and economic analysis}

The design and calculation of rock bolt foundation, rock fixed foundation and hole digging foundation are carried out respectively with the foundation force and geological parameters as input conditions. The concrete, basic steel and other major engineering quantities and economic costs are compared with the composite bolt foundation. The specific comparison is shown in Table 2.

Table 2 Comparison table of basic engineering amount and ontology cost

\begin{tabular}{|c|c|c|c|c|c|c|}
\hline Basic type & $\begin{array}{c}\text { Basic model and size } \\
(\mathrm{m})\end{array}$ & $\begin{array}{c}\text { concrete } \\
(\mathrm{m}) 3\end{array}$ & $\begin{array}{c}\text { reinforced } \\
(\mathrm{kg})\end{array}$ & $\begin{array}{c}\text { Earthwork } \\
\text { quantity } \\
(\mathrm{m}) 3\end{array}$ & $\begin{array}{c}\text { drilling } \\
(\mathrm{m})\end{array}$ & $\begin{array}{c}\text { cost } \\
(\mathrm{RMB})\end{array}$ \\
\hline
\end{tabular}




\begin{tabular}{|c|c|c|c|c|c|c|}
\hline The rock bolt & $\begin{array}{c}\text { Cap: } 2.52 .53 .2 \\
\text { Anchor: } 245.50 .12\end{array}$ & 12.9 & 2981 & 18.8 & 132 & 67821 \\
\hline Embedded rock solid & 2.43 .56 .0 & 33.8 & 1473 & 33 & 0 & 68930 \\
\hline $\begin{array}{c}\text { Excavated } \\
\text { foundation }\end{array}$ & 1.82 .810 .2 & 36.45 & 2235 & 36.0 & 0 & 77607 \\
\hline $\begin{array}{c}\text { Composite bolt } \\
\text { basis }\end{array}$ & $\begin{array}{c}\text { Build-in: } 3.44 .72 .4 \\
\text { Anchor: } 104.50 .12\end{array}$ & 24.3 & 1411 & 24 & 45 & 61527 \\
\hline
\end{tabular}

It can be seen from the above table that compared with rock bolt, composite bolt has obvious cost advantages. Compared with the rock embedded foundation, the concrete content of composite bolt foundation is obviously superior and the cost of material itself is also small. Compared with the hole-digging foundation, the concrete consumption and steel consumption of composite bolt foundation are also lower, and the cost of material body is also smaller. The economic and technological advantages of composite bolt foundation are as follows: the composite bolt foundation covers a small area, has less earthwork, significantly reduces the amount of concrete, saves steel, reduces the damage to the surrounding environment, reduces the project cost, and has significant economic and social benefits.

\section{Construction technology of composite bolt foundation}

In order to ensure the stability of the upper undisturbed soil and rock mass, according to the characteristics of the composite bolt foundation, it is suggested that the composite bolt foundation should follow the procedure of "cut and dig first, then planting reinforcement".

\section{Summary}

(1) The upper have certain turns the soil, but lower bedrock traits better rock region, composite anchor foundation can pilot application based style: the new type for the upper layer thicker and easy excavation DaWei pilot choose composite bolt pile foundation of forming with $30^{\circ}$, coating thickness gradient is greater than $2 \mathrm{~m}$ DaWei pilot selects the built-in composite anchor foundation.

(2) When selecting composite foundation, it is necessary to carry out field true type test of composite bolt foundation based on the selected tower position, determine the proportion coefficient of ultimate tensile strength of the upper undisturbed foundation and the lower bolt foundation, reasonably control the rock-socketed depth of the upper undisturbed foundation, and improve the eccentric tension state of the bottom bolt.

\section{References}

1. Chen rong, Gao yucong, Meng xianbin, Hao dongxue. Journal of northeast dianli university. 2015(06)

2. Hou zhongwei, Zheng weifeng. Electric power construction. 2014(10)

3. Design and application of new composite foundation for transmission lines $[\mathrm{J}]$. Ding shijun, Jin jianhua, Lu xianlong. Journal of wuhan university (engineering science edition). 2011(S1)

4. Experimental study on cut-and-cut foundation of transmission lines $[\mathrm{J}]$. Teng junlin, ding shijun, Wang jianxun, Zhao huaiyu, Zheng dengxian. Engineering investigation. 2010(09)

5. Zheng weifeng, Lu xianlong, Cheng yongfeng, Feng zixia. Engineering investigation. 2010(01)

6. Current situation and prospect of power transmission line foundation engineering in China $[\mathrm{J}]$. Lu xianlong, Cheng yongfeng. Electric power construction. 2005(11)

7. The status quo and existing problems of power transmission line foundation engineering in China [J]. Cheng yongfeng, Shao xiaoyan, Zhu quanjun. Power construction. 2002(03) 